Jurnal Akuntansi dan Investasi, Vol. 17 No. 2, Hlm: 104-117, Juli 2016

Artikel ini tersedia di website: http://journal.umy.ac.id/index.php/ai

DOI: 10.18196/jai.2016.0048.104-117

\title{
Faktor-Faktor Internal Individual dalam Pembuatan Keputusan Etis: Studi pada Konsultan Pajak di Kota Surabaya
}

\author{
Martana Arrazaqu Arestanti; Nurul Herawati*; Emi Rahmawati \\ Program Studi Akuntansi Universitas Trunojoyo Madura, Jl. Raya Telang, Bangkalan, Madura, Jawa Timur, Indonesia
}

\section{ART I C LE IN F O \\ Article history: \\ received 15 Nov 2015 \\ revised 25 Feb 2016 \\ accepted 17 Mar 2016}

\section{Keywords:}

Perception, Ethics, Social Responsibility,

Machiavellianism,

Ethical Reasoning,

Ethical Decision Making

\begin{abstract}
A B S T RACT
This study aims to examine the influence of individual factors (perception of the importance of ethical and social responsibility; machiavellianism; ethical reasoning) toward ethical decision making of tax consultants. This study used 50 tax consultants as the study samples in Tax Consultant Office in Surabaya. The method of data analysis using regression analysis. This study reveals perception of the importance of ethical and social responsibility have positive influence toward ethical decision making by tax consultant, machiavellianism have negative influence toward ethical decision making by tax consultant and ethical reasoning have positive imfluence toward ethical decision making. The implication of this study is a person who has a high perception of the importance of ethical and responsibility supporting that person to conduct ethical decision making. The General Director of Taxation or the official which is delegated in issuing tax practical license needed to conduct a machiavellianism trait test from tax consultant itself. Besides, it also takes to be ensured that the tax consultant who have had the licence is an individual who has a high moral maturity (post conventional stage), so that the possibilities will be less to approve the non-ethical act and more independent in decision making which is related to ethical dilemma.
\end{abstract}

(C) 2016 JAI. All rights reserved

\section{PENDAHULUAN}

Indonesia menggunakan self assessment system dalam penerapan perpajakannya. Sistem ini merupakan sistem pemungutan pajak yang memberikan kepercayaan kepada wajib pajak untuk menghitung, membayar, dan melaporkan sendiri pajak yang terutang sesuai dengan ketentuan perpajakan yang berlaku. Namun beberapa studi seperti Noviati (1997); Damayanti (2004); dan Tarjo dan Kusumawati (2006) menemukan bahwa pelaksanaan self assessment system belum berjalan baik. Studi Novianti (1997) menemukan bahwa pelaksanaan self assessment belum bisa diterapkan oleh wajib pajak Orang Pribadi terutama pemilik koskosan, karena mereka sering kali tidak melaporkan atau mencantumkan pajak penghasilannya pada Surat Pemberitahuan (SPT). Studi Damayanti (2004) menunjukkan bahwa self assessment system untuk wajib pajak badan di Salatiga belum berjalan dengan baik. Studi Tarjo dan Kusumawati (2006) menemukan bahwa self assessement system di Bangkalan belum terlaksana dengan baik. Karena wajib pajak masih banyak yang tidak menghitung sendiri pajak terutangnya meskipun dalam fungsi membayar sudah baik karena wajib pajak telah menyetorkan pajak terutangnya sebelum jatuh tempo, tetapi ada wajib pajak yang membayar pajak terutang tidak sesuai dengan penghitungannya. Sedangkan dalam kasus pelaporan pajak, meskipun wajib pajak sudah melaksanakan pelaporan, namun hal itu dilakukan bukan karena kesadaran mereka sendiri tetapi karena adanya denda.

Menurut studi Tarjo dan Kusumawati (2006) terhadap 56 wajib pajak di Bangkalan (lihat Tabel 1), tidak semua wajib pajak mengerti dan memahami peraturan perpajakan dan implementasinya. Prosentase wajib pajak yang tidak memiliki pengetahuan mengenai tarif pajak yang berlaku sebesar $69,6 \%$. Prosentase wajib pajak yang tidak mengetahui perubahan peraturan perpajakan sebesar 78,6\%. Prosentase wajib pajak yang tidak mampu menghitung pajak sebesar $57,1 \%$. Prosentase wajib pajak yang pernah melakukan kesalahan dalam perhitungan pajak penghasilan sebesar $53,6 \%$. Sementara, Tingkat kesalahan yang pernah dibuat oleh wajib pajak sebe- 
Tabel 1. Partisipasi Wajib pajak untuk Menghitung Besarnya Pajak Terutang

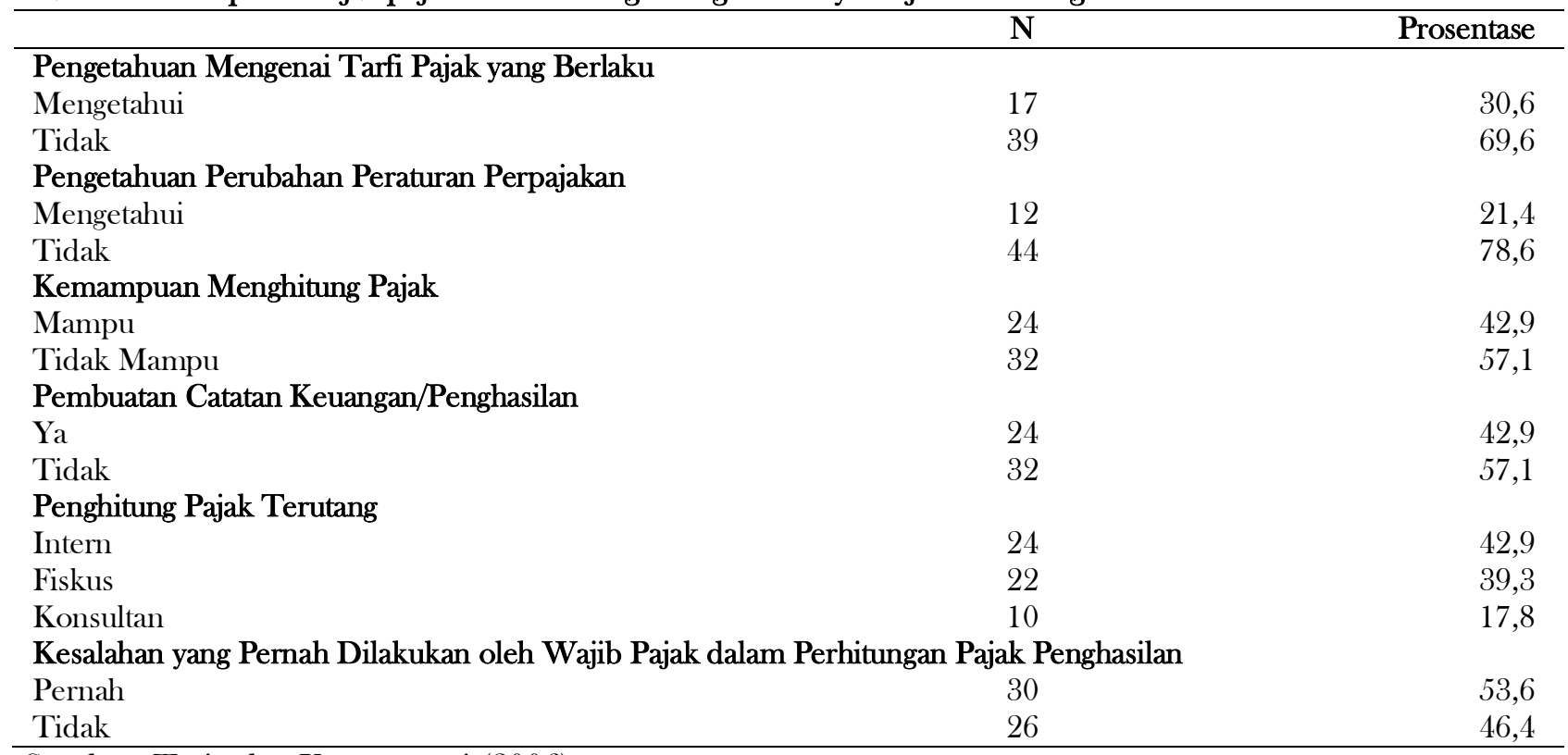

Sumber: Tarjo dan Kusumawati (2006)

sar 53,6\%. Tingkat kesalahan ini cukup tinggi sehingga bisa jadi menjadi alasan kenapa wajib pajak menggunakan jasa konsultan pajak dalam perhitungan pajaknya. Menurut Sugianto (Jawa Pos, 2008), jasa konsultasi pajak terus berkembang dan semakin diminati wajib pajak. Sugianto (Jawa Pos, 2008) juga mengatakan tahun 2008, secara kumulatif, jasa konsultasinya melayani lebih dari 150 perusahaan, dengan sekitar 500 penugasan dan trendnya terus meningkat.

Sugiono menyatakan maraknya pengguna jasa konsultan pajak juga disebabkan banyaknya aturan baru yang terbit tahun 2008 (Jawa Pos, 2008). Devos (2012) menyatakan wajib pajak menggunakan konsultan pajak-untuk mewakilinya-dengan sejumlah alasan. Alasan-alasan yang dinyatakan Devos (2012) antara lain: keinginan untuk melaporkan SPT yang akurat terutama karena kurangnya pengetahuan pajak mereka berdasarkan kompleksitas hukum pajak saat ini, keinginan untuk meminimalkan pajak mereka yang diwajibkan untuk dibayar, ketakutan mereka akan membuat kesalahan dan dikenai sanksi, atau hanya karena kurangnya waktu untuk menyelesaikannya. Cash et al. (2007) menyatakan konsultan pajak harus terus memberikan pelayanan terbaik yang mereka bisa untuk kliennya, termasuk pengurangan pajak ketika hal itu dapat dilakukan dengan cara yang etis dan berdasarkan hukum dan dalam kepentingan terbaik dari klien.

Gupta (2015) menemukan bahwa klien lebih memilih penjelasan yang terbatas dari implikasi peraturan perpajakan terkait dengan urusan pajak mereka dan kewajiban mereka berdasarkan hukum pajaknya. Studi Tan (1999) menemukan bahwa wajib pajak, yang adalah pemilik bisnis yang didominasi kecil, lebih setuju dengan rekomendasi konservatif yang diberikan oleh konsultan pajak. Menariknya, wajib pajak juga setuju, meskipun kurang kuat, dengan rekomendasi agresif dari konsultan pajak mereka. Sekjen Komwas Perpajakan dalam Achmad (2014) menyatakan:

"Profesi ideal konsultan pajak harus memiliki independensi, profesionalisme, dan integritas dalam menjalankan bisnis industrinya”.

Konsultan pajak memiliki kode etik untuk menjaga independensi, profesionalisme, dan integritasnya dalam menjalankan profesinya. Disisi lain, studi Tan (1999) menunjukkan bahwa ada kecenderungan bagi klien yang tidak setuju dengan rekomendasi konsultan pajaknya dan memilih untuk mengakhiri penggunaan jasanya, meskipun tidak ada bukti yang jelas untuk menunjukkan bahwa ini hanya terjadi ketika keinginan mereka untuk rekomendasi konservatif tidak terpenuhi. Disinilah dibutuhkan pembuatan keputusan etis oleh seorang konsultan pajak. Blanthorne et al. (2014) menyatakan bahwa isu ini muncul sebagai akibat dari adanya masalah dual agency pada hubungan antara konsultan pajak dengan klien; di satu sisi konsultan pajak perlu membina hubungan baik dengan klien, namun disisi lain konsultan pajak memiliki kewajiban untuk mematuhi peraturan pajak.

Purnamasari (2006) memaparkan bahwa kepribadian individu mempengaruhi perilaku etis. Penelitian terkait dengan perilaku etis telah banyak dilakukan. Penelitian yang meneliti perilaku etis mahasiswa dan akuntan dilakukan oleh Richmond 
(2001), Chrismastuti dan Purnamasari (2004), Anton (2012), Sari et al. (2012) dan Arif et al. (2014). Sementara, penelitian yang meneliti perilaku etis auditor dalam menghadapi dilema etika dan konflik yang dapat menurunkan independensi, seperti Nugrahaningsih (2005), Purnamasari (2006), Pramono dan Ario (2009), Safitri (2013). Penelitian perilaku etis wajib pajak pernah dilakukan oleh Ramadhani (2015). Penelitian perilaku etis konsultan pajak dalam menghadapi dilema etika dan konflik yang dapat menurunkan independensi dilakukan oleh Burns dan Kiecker (1995), Shafer dan Simmons (2008), Bobek et al. (2010), Doyle et al. (2013), Doyle et al. (2014), Hughes et al. (2016). Di Indonesia juga telah dilakukan oleh Jiwo (2011), dan Krismanto (2014). Jiwo (2011) meneliti konsultan pajak di KAP di kota Semarang, sedangkan Kris-manto (2014) meneliti konsultan pajak dan staff pajak di beberapa Kantor Konsultan Pajak Bandung.

Studi ini merupakan penelitian replikasi dari Shafer dan Simmons (2008) dan Jiwo (2011), dengan menguji kembali pengaruh faktor-faktor yang mempengaruhi pembuatan keputusan etis seorang konsultan pajak, khususnya yang berada di kota Surabaya. Studi ini meliputi persepsi pentingnya etika dan tanggung jawab sosial, sifat machiavellian dan pertimbangan etis dalam pembuatan keputusan etis. Dua pertimbangan yang membuat penelitian ini penting dilakukan adalah karena kasus-kasus perpajakan yang ada telah menjadi fenomena tersendiri dalam dunia perpajakan. Di Surabaya, terdapat kasus 13 konsultan pajak dijebloskan ke penjara (Amarullah, 2010) karena memalsukan SSP dan uangnya tidak disetorkan tapi untuk keperluan pribadi serta berkonspirasi dengan lima PNS Pajak yang bertugas di lingkungan Kanwil Direktorat Jenderal Pajak Jatim I Jl Jagir. Di tingkat nasional, kasus dugaan korupsi pajak dan pencucian uang Dhana Widyatmika pada tahun 2012 melibatkan konsultan pajak (Beritasatu.com 2012). Perusahaan (Wajib pajak) diduga melibatkan konsultan pajak dan Dhana Widyatmika (aparatur pajak) menangani resititusi pajak perusahaannya.

Pertimbangan lainnya adalah perbedaan budaya yang ada di setiap masyarakat dimana profesi itu berada. Hunt dan Vitell (1986) menyebutkan kemampuan seorang profesional untuk dapat mengerti dan sensitif akan adanya masalah-masalah etika dalam profesinya dipengaruhi oleh lingkungan budaya atau masyarakat di mana profesi itu berada, lingkungan profesi, lingkungan organisasi dan pengalaman pribadi. Hudson dan Miller (2005) menemukan ada sejumlah faktor yang mempengaruhi pengambilan keputusan etis mahasiswa, salah satunya adalah latar belakang budaya.
Kota Surabaya merupakan kota metropolitan kedua setelah ibu kota Jakarta. Kota Surabaya memiliki beragam kebudayaan dari Madura, Islam, Arab, Tionghoa, dan etnis lainnya yang berdiam di Surabaya. Keanekaragaman budaya inilah yang menarik untuk diuji kembali faktor internal individu konsultan pajaknya di kota Surabaya. Selain itu, terdapat kemungkinan hasil penelitian yang berbeda terkait dengan faktor internal individu konsultan pajak di lingkungan budaya atau masyarakat di kota Surabaya.

\section{TINJAUAN LITERATUR DAN PERUMUSAN HIPOTESIS}

\section{Teori Pengambilan Keputusan Etis dan Teori Perkembangan Moral}

Definisi keputusan etis menurut Sparks dan Pan (2009) "ethical decision is an individual's selection of the most ethical decision among the different alternatives." Individu memiliki beberapa alternatif pilihan dan pemilihan yang paling etis merupakan keputusan etis. Ferrell dan Gresham (1985) menyusun sebuah kerangka untuk memahami proses pengambilan keputusan etis. Model mendemonstrasikan bagaimana riset-riset sebelumnya dapat diintegrasikan untuk mengungkapkan keputusan etis, dimoderasi dengan faktor individu, signifikan dengan setting organisasi dan kesempatan untuk melakukannya. Kerangka tersebut memberikan simpulan bahwa apabila seseorang menghadapi sebuah dilema etis, maka perilaku yang muncul dipengaruhi oleh interaksi antara karakteristik-karakteristik yang berhubungan dengan individu dan faktor di luar individu. Hunt dan Vitell (1986) mendefinisikan pengambilan keputusan etis sebagai pengambilan keputusan dengan pemahaman mengenai sebuah tindakan benar secara moral atau tidak.

Pengambilan keputusan etis melibatkan proses penalaran etis yang di dalamnya mengolaborasi kesadaran moral dan kemampuan moral kognitif seseorang yang pada akhirnya diwujudkan di dalam proses tindakan sebagai bentuk implementasi keputusan yang diambil (Wisesa, 2011). Pengambilan keputusan etis menurut Rest et al. (1997) adalah "a psychologically structured process which causes an individual facing an ethical dilemma to make a morally right or morally wrong evaluation." Pembuatan keputusan etis merupakan sebuah proses psikologis ketika menghadapi dilema etis dalam membuat penilaian benar atau salah secara moral. Teori perkembangan moral menjelaskan bagaimana tahapan penalaran moral seseorang. 
Studi Lawrence Kohlberg (1976) mengidentifikasi tiga tingkatan perkembangan moral. Seorang individu pada tingkat pertama (pre-conventional) perkembangan moral menganggap harapan masyarakat menjadi eksternal untuk dirinya sendiri. Pada tingkat ini, outcome perilaku yang tampaknya etis dapat termotivasi oleh keinginan individu untuk menghindari hukuman atau hasilnya (outcome) berada dalam kepentingan diri individu. Misalnya, anak kecil biasanya berperilaku dengan cara tertentu semata-mata untuk menerima imbalan atau untuk menghindari hukuman.

Pada tingkat kedua (convensiona), seorang individu bersangkutan dengan masyarakat, kesejahteraan orang lain, dan persepsi orang lain untuk moralitasnya. Misalnya, remaja yang umumnya dianggap dipengaruhi oleh tekanan teman sebaya yang menunjukkan tingkat kedua kemampuan penalaran moral. Seorang individu yang telah mencapai tingkat ketiga (post-conventiona), dan akan bertindak atas nama, orang lain dalam masyarakat. Individu-individu ini percaya bertindak untuk kepentingan publik dan hak-hak individu yang ada secara independen dari masyarakat. Berdasarkan teori perkembangan moral di atas, dapat dijelaskan bahwa semakin tinggi tingkat perkembangan moral seseorang, maka semakin tinggi tingkat moralitasnya (Jiwo, 2011).

\section{Konsultan Pajak}

Definisi konsultan pajak menurut Peraturan Menteri Keuangan Republik Indonesia Nomor 111/PMK.03/2014 tentang konsultan pajak, adalah orang yang memberikan jasa konsultasi perpajakan kepada wajib pajak dalam rangka melaksanakan hak dan memenuhi kewajiban perpajakannya sesuai dengan peraturan perundang-undangan perpajakan. Salah satu kewajiban Konsultan Pajak dalam pasal 23 PMK No. 111/PMK. 03/2014 adalah memberikan jasa konsultasi kepada wajib pajak dalam melaksanakan hak dan memenuhi kewajiban perpajakan sesuai dengan peraturan perundang-undangan perpajakan. Budileksmana (2000) dan Achmad (2014) menyatakan konsultan pajak memiliki fungsi tax consulting, tax settlement, tax mediation, attorney at tax law, dan agent of tax awareness.

Hughes dan Moizer (2015) membagi jasa yang disediakan oleh konsultan pajak menjadi dua jenis: kepatuhan pajak dan perencanaan pajak/penghindaran pajak. Kepatuhan pajak mencakup jasa yang melibatkan persiapan perhitungan pajak untuk diserahkan mewakili wajib pajak kepada otoritas pajak yang relevan, dan berurusan dengan dan mengatasi setiap pertanyaan berikutnya dan ketidakpastian yang ada. Ini melibatkan pelaporan peristiwa ekonomi yang terjadi, dimana konsultan pajak berfungsi untuk memastikan bahwa pelaporan sesuai dengan undangundang pajak. Terkadang undang-undang pajak mengandung daerah 'abu-abu' atau hukum tidak jelas, disitulah peran konsultan pajak diperlukan untuk memastikan tidak melanggar hukum pajak yang ada. Perencanaan pajak/penghindaran (atau pencegahan) terjadi ketika praktisi pajak berupaya untuk menemukan cara-cara untuk mengurangi kewajiban wajib pajak. Mardiasmo sebagaimana dikutip Jefriando (2015) mengatakan, profesi konsultan pajak memiliki tanggung jawab yang besar. Sebab, konsultan pajak seringkali menjadi teladan bagi para wajib pajak sehingga harus memberikan masukan yang benar.

Hughes dan Moizer (2015) membagi jasa yang disediakan oleh praktisi pajak kedalam dua jenis, yaitu rekomendasi kepatuhan pajak (tax compliance) dan perencanaan/penghindaran pajak (tax planning/ avoidance). Masih menurut Hughes dan Moizer (2015), jasa kepatuhan pajak biasanya melibatkan persiapan perhitungan pajak untuk pelaporan atas nama wajib pajak kepada otoritas pajak yang relevan, dan berurusan dengan dan menyelesaikan setiap pertanyaan berikutnya dan ketidakpastian. Pada situasi ini pelibatan praktisi pajak bertujuan untuk memastikan bahwa pelaporan sesuai dengan undangundang pajak. Sementara itu, undang-undang pajak mungkin berisi daerah 'abu-abu' hukum tidak jelas, kadang-kadang situasi dimana undang-undang yang diterapkan ambigu. Jasa perencanaan/penghindaran pajak (atau mitigasi) terjadi ketika praktisi pajak mencoba untuk menemukan cara-cara untuk mengurangi kewajiban wajib pajak.

Peraturan Menteri Keuangan Republik Indonesia Nomor 111/PMK.03/2014 tentang konsultan pajak, pasal 3 menyatakan untuk dapat berpraktik sebagai konsultan pajak, seorang konsultan pajak yang telah memenuhi persyaratan, harus mempunyai izin praktik yang diterbitkan oleh Direktur Jenderal Pajak atau pejabat yang ditunjuk. Pasal 4 ayat 1 menyatakan izin praktik yang diberikan kepada konsultan pajak terdiri dari: izin praktik tingkat $\mathrm{A}$; izin praktik tingkat $\mathrm{B}$; dan izin praktik tingkat $\mathrm{C}$. Pasal 4 ayat 2 menyatakan izin praktik tingkat $\mathrm{A}$ diberikan kepada konsultan pajak yang memiliki sertifikat konsultan pajak tingkat A. Pasal 4 ayat 3 menyatakan izin praktik tingkat $\mathrm{B}$ diberikan kepada konsultan pajak yang memiliki sertifikat konsultan pajak tingkat B.Pasal 4 ayat 4 menyatakan izin praktik tingkat C diberikan kepada konsultan pajak yang memiliki sertifikat konsultan pajak tingkat $\mathrm{C}$.

Peraturan Menteri Keuangan Republik Indonesia Nomor 111/PMK.03/2014 tentang konsultan pajak, pasal 8 menyatakan: sertifikat konsultan pajak tingkat A, yaitu sertifikat konsultan pajak yang 
menunjukkan tingkat keahlian untuk memberikan jasa di bidang perpajakan kepada wajib pajak orang pribadi dalam melaksanakan hak dan memenuhi kewajiban perpajakannya, kecuali wajib pajak yang berdomisili di negara yang mempunyai persetujuan penghindaran pajak berganda dengan Indonesia; sertifikat konsultan pajak tingkat B, yaitu sertifikat konsultan pajak yang menunjukkan tingkat keahlian untuk memberikan jasa di bidang perpajakan kepada wajib pajak orang pribadi dan wajib pajak badan dalam melaksanakan hak dan memenuhi kewajiban perpajakannya, kecuali kepada wajib pajak penanaman modal asing, bentuk usaha tetap, dan wajib pajak yang berdomisili di negara yang mempunyai persetujuan penghindaran pajak berganda dengan Indonesia; dan sertifikat konsultan pajak tingkat C, yaitu sertifikat konsultan pajak yang menunjukkan tingkat keahlian untuk memberikan jasa di bidang perpajakan kepada wajib pajak orang pribadi dan wajib pajak badan dalam melaksanakan hak dan memenuhi kewajiban perpajakannya.

\section{Persepsi Pentingnya Etika, Tanggung Jawab Sosial dan Pembuatan Keputusan Etis}

Gray et al. (2012) menjelaskan persepsi sebagai berikut:

“...mind perception entails ascribing mental capacities to other entities, whereas moral judgment entails labeling entities as good or bad or actions as right or wrong. We suggest that mind perception is the essence of moral judgment."

Gray et al. (2012) juga menyatakan persepsi pikiran adalah hakikat penilaian moral. Kohlberg (1976) mengidentifikasi tiga tingkatan perkembangan moral. Semakin tinggi tingkat perkembangan moral seseorang, maka semakin tinggi tingkat moralitasnya. Sementara, Singhapakdi et al. (2001) menyatakan bahwa:

"This is a pragmatic view based on an argument that managers must first perceive ethics dan social responsibility to be vital to organizational effectiveness before their behaviors will become more ethical dan reflect greater social responsibility."

Dari kutipan di atas, seorang manajer mempersepsikan bahwa etika dan tanggung jawab sosial menjadi penting untuk efektivitas organisasi sebelum perilaku mereka akan menjadi lebih etis dan mencerminkan tanggung jawab sosial yang lebih besar. Dengan demikian, dari perspektif praktis, persepsi pentingnya etika dan tanggung jawab sosial untuk keberhasilan organisasi cenderung menjadi faktor penting dalam perilaku bisnis yang sebenarnya.

Singhapakdi et al. (1995) meneliti pengaruh nilai-nilai etika perusahaan dan filosofi moral pribadi terhadap pentingnya etika dan tanggung jawab sosial dari profesional pemasaran. Hasil penelitiannya menunjukkan bahwa ada hubungan positif antara nilai-nilai etika perusahaan pemasar dan persepsipersepsinya mengenai pentingnya etika dan tanggung jawab sosial. Hasil penelitiannya juga mengungkapkan bahwa persepsi pentingnya etika dan tanggung jawab sosial pemasar (marketers) sebagian dapat dijelaskan oleh filsafat moral mereka (idealisme dan relativisme). Singhapakdi et al. (1996) mengembangkan intrumen yang handal dan valid untuk mengukur bagaimana para pemasar (marketer) mempersepsikan peran etika dan tanggung jawab sosial dalam sebuah organisasi yang efektif.

Kurpis et al. (2008) mencatat bahwa karena sifat khusus dari bisnis, profesional bisnis cenderung menghadapi dilema etika yang unik untuk profesi mereka. Demikian juga dengan profesi konsultan pajak. Isu pengambilan keputusan etis konsultan pajak sebagai akibat dari adanya masalah dual agency pada hubungan antara konsultan pajak dengan klien; di satu sisi konsultan pajak perlu membina hubungan baik dengan klien, namun disisi lain konsultan pajak memiliki kewajiban untuk mematuhi peraturan pajak (Blanthorne et al., 2014).

Shafer dan Simmons (2008) mengkaji pengaruh perilaku terhadap persepsi pentingnya etika perusahaan dan tanggung jawab sosial pada kesediaan praktisi pajak profesional untuk mengadvokasi skema penghindaran agresif atas nama klien perusahaan. Studi Shafer dan Simmons (2008) berhipotesis bahwa praktisi yang mempersepsikan etika perusahaan dan tanggung jawab sosial tersebut lebih penting akan menilai penghindaran (avoidance) agresif kurang menguntungkan, dan karenanya akan memperkirakan kemungkinan yang lebih rendah dari persetujuan dalam skema tersebut. Temuan, berdasarkan survei dari para profesional pajak di Hong Kong, mendukung hipotesis. Jiwo (2011) menjelaskan bahwa konsultan pajak di Kantor Akuntan Publik (KAP) Semarang memiliki pemahaman etika yang baik dalam menjalankan pekerjaannya konsultan pajak mempunyai persepsi terhadap pentingnya etika dan tanggung jawab sosial yang tinggi dan baik. Oleh karena itu, penelitian ini berupaya menguji bagaimanakah pengaruh persepsi konsultan perpajakan atas pentingnya etika dan tanggung jawab sosial terhadap pengambilan keputusan etis. Berdasarkan penjelasan-penjelasan tersebut, maka hipotesis satu yang dirumuskan adalah sebagai berikut: 
$\mathrm{H}_{1}$ : Persepsi pentingnya etika dan tanggung jawab sosial berpengaruh positif terhadap pembuatan keputusan etis oleh konsultan pajak.

\section{Sifat Machiavellianisme dan Pembuatan Keputusan Etis}

Teori pengambilan keputusan etis yang dimodelkan Ferrell dan Gresham (1985) menjelaskan bahwa apabila seseorang menghadapi sebuah dilema etis, maka perilaku yang muncul dipengaruhi oleh interaksi antara karakteristik-karakteristik yang berhubungan dengan individu. Individu machiavellian digambarkan sebagai kurang melibatkan emosi dengan orang lain, memiliki sedikit hubungan interpersonal, dan cenderung lebih menolak normanorma etika untuk mencapai tujuan pribadi (Christie dan Geis, 1970). Rayburn dan Rayburn (1996) meneliti hubungan antara karakter kepribadian (personality traits) dan orientasi etis mahasiswa akuntansi. Rayburn dan Rayburn (1996) menemukan individudengan intelegensi yang tinggi-lebih machiavellian dan berkepribadian tipe A tetapi berorientasi kurang etis daripada individu dengan kecerdasan lebih rendah. Machiavellians cenderung memiliki kepribadian tipe $\mathrm{A}$, tetapi cenderung berorientasi kurang etis dari Non machiavellians. Namun, individu dengan kepribadian tipe A berorientasi lebih etis daripada individu dengan kepribadian Tipe B. Christie dan Geis (1970) menyatakan bahwa:

"Machiavellianism as a construct represents a set of behaviors that include lack of conventional morality, negativism dan emotional detachment."

Machiavellianism sebagai konstruk yang melambangkan serangkaian perilaku yang meliputi kurangnya moralitas, sikap negatif dan detasemen emosional. Richmond (2001) menjelaskan bahwa kecenderungan sifat machiavellian yang semakin tinggi maka seseorang akan cenderung untuk berperilaku tidak etis. Sebaliknya, jika kecenderungan sifat machiavellian rendah maka seseorang akan cenderung untuk berperilaku etis. Murphy (2012) menemukan bahwa akuntan machiavellian lebih cenderung melaporkan laporan keuangan secara keliru dibandingkan dengan machiavellianism yang lebih rendah. Purnamasari (2006) menjelaskan bahwa individu dengan sifat machiavellian tinggi cenderung memanfaatkan situasi untuk mendapatkan keuntungan pribadi dan lebih memiliki keinginan untuk tidak taat pada aturan. Penelitian yang ada secara konsisten menemukan bahwa machiavellian menunjukkan nilai-nilai etika yang rendah.

Studi Shafer dan Simmons (2008) berhipotesis bahwa praktisi pajak profesional dengan orientasi machiavellian kuat akan cenderung merasa bahwa etika perusahaan dan tanggung jawab sosial itu penting, dan lebih cenderung menilai skema penghindaran pajak agresif menguntungkan. Temuan, berdasarkan survei dari para profesional pajak di Hong Kong, mendukung hipotesis tersebut. Berangkat dari temuan tersebut maka studi ini berupaya menguji bagaimana pengaruh machiavellianisme terhadap pembuatan keputusan etis oleh konsultan pajak di kota Surabaya. Sehingga hipotesis kedua dalam penelitian ini dirumuskan sebagai berikut:

$\mathrm{H}_{2}$ : Sifat machiavellian berpengaruh negatif terhadap pembuatan keputusan etis oleh konsultan pajak.

\section{Pertimbangan Etis dan Pembuatan Keputusan Etis}

Ponemon (1992) menyatakan bahwa level pertimbangan etis yang lebih tinggi akan meningkatkan sensitifitas seorang individu untuk lebih mengkritisi kejadian, masalah dan konflik. Auditor dengan kapasitas pemikian etis yang tinggi akan lebih baik dalam menghadapi konflik dan dilema etis, dan lebih independen dalam membuat keputusan yang terkait dengan dilema etis. Sweeney dan Roberts (1997) meneliti apakah pertimbangan etis berpengaruh pada penilaian independensi seorang auditor. Temuan yang paling signifikan adalah tingkat perkembangan moral auditor mempengaruhi kepekaannya terhadap masalah etika dan keputusan independen.

Purnamasari (2006) menyatakan pertimbangan etis yang tinggi akan lebih baik dalam menghadapi konflik dan dilema etis, bahwa individu yang lebih berkembang secara moral (pertimbangan etisnya lebih tinggi) kemungkinannya akan lebih kecil untuk menyetujui perilaku yang tidak etis dan lebih independen dalam membuat keputusan yang terkait dengan dilema etis. Fleischman et al. (2007) meneliti persepsi manajer profesional-dengan menggunakan dua sketsa situasional-untuk menyelidiki secara empiris dua dari empat langkah dari Rest (1986) terkait proses pertimbangan etis dan menemukan indikasi bahwa proses pertimbangan etis secara signifikan berhubungan dengan pengambilan keputusan etis.

Jiwo (2011) menyatakan pertimbangan etis telah menjadi komponen penting dalam studi mengenai kepribadian dalam profesi akuntansi karena banyak pertimbangan profesional yang ditentukan berdasarkan keyakinan dan nilai-nilai individual. Profesi akuntansi, termasuk dalam perpajakan, selalu berhadapan dengan tekanan untuk mempertahankan standar etika yang tinggi di tengah kompetisi yang terus meningkat. Beberapa penelitian terdahulu seperti yang terangkum. Jiwo (2011) menyarankan individu yang berkembang dengan moral yang lebih baik, kecil 
kemungkinannya berperan dalam kepribadian yang tidak etis. Blanthorne et al. (2014) menemukan bahwa pertimbangan moral mempengaruhi keputusan pelaporan pajak agresif terpisah dari pengaruh tekanan klien. Karena tingkat pertimbangan moral meningkat, posisi pelaporan agresivitas ditemukan juga menurun. Seorang konsultan pajak dengan pertimbangan etis yang baik diharapkan dapat membuat keputusan yang cenderung etis, sehingga hipotesis ketiga penelitian ini dirumuskan sebagai berikut.

$\mathrm{H}_{3}$ : Pertimbangan etis berpengaruh terhadap pembuatan keputusan etis oleh konsultan pajak.

\section{METODE PENELITIAN}

\section{Sampel Penelitian}

Sampel penelitian ini adalah 50 orang konsultan pajak bersertifikat di kota Surabaya. Kriteria sampel yang digunakan adalah: (1) warga negara Indonesia; (2) berprofesi sebagai konsultan pajak; dan (3) memiliki sertifikat konsultan pajak. Alasan kriteria sampel ini adalah sesuai dengan kriteria konsultan pajak dalam Peraturan Menteri Keuangan Republik Indonesia No. 111/PMK. 03/2014 tentang konsultan pajak. Dalam penyebaran kuesioner tidak semua Kantor Konsultan Pajak (KKP) di kota Surabaya mau menerimanya. Terdapat $25 \mathrm{KKP}$ yang tidak bersedia menerima kuesioner dikarenakan konsultan pajaknya tidak bersedia menjadi responden. Hanya terdapat 55 KKP yang bersedia dalam menerima penyebaran kuisioner yang berlokasi di Surabaya. Hasil akhir sampel yang kembali dan dapat diolah adalah sebanyak 50 kuisioner.

\section{Definisi Operasional Variabel Penelitian}

\section{Variabel Independen}

\section{Persepsi Pentingnya Etika dan Tanggung Jawab Sosial}

Etika mengacu pada sistem atau kode perilaku kewajiban moral yang menunjukan bagaimana seorang individu harus berperilaku dalam masyarakat (Kurniawan dan Sadjiarto, 2013). Prinsip-prinsip etika profesional dinyatakan dalam lima butir prinsip (Sukrisno, 1996) sebagai berikut:

(1) Tanggung jawab, yaitu mewujudkan kepekaan profesional dan pertimbangan moral dalam semua aktivitas;

(2) Kepentingan masyarakat, yaitu menghargai kepercayaan masyarakat dan menunjukkan komitmen pada profesionalisme;
(3) Integritas, yaitu melaksanakan semua tanggung jawab profesional dengan rasa integritas yang tinggi;

(4) Obyektivitas dan independensi, yaitu mempertahankan obyektivitas dan terlepas dari konflik kepentingan dalam melakukan tanggung jawab profesional, serta independen dalam kenyataan dan penampilan pada waktu melaksanakan aktivitas jasanya;

(5) Lingkup dan sifat jasa, yaitu mematuhi kode etik perilaku profesional untuk menentukan lingkup dan sifat jasa yang akan diberikan. Beberapa penelitian menunjukkan bahwa sikap terhadap pentingnya kode etik perusahaan dan tanggung jawab sosial memiliki pengaruh penting terhadap proses pengambilan keputusan etis.

Indikator dari persepsi pentingnya etika dan tanggung jawab sosial adalah: (1) konsultan pajak bertanggung jawab atas profesinya; (2) konsultan pajak selalu sopan dan ramah; dan (3) konsultan pajak mematuhi kode etik. Variabel persepsi pentingnya etika dan tanggung jawab sosial akan diukur dengan cara menyebarkan kuesioner dengan menggunakan skala Likert dari interval 1 (sangat tidak setuju) hingga interval 5 (sangat setuju).

\section{Sifat Machiavellianisme}

Machiavellianisme didefinisikan sebagai "sebuah proses dimana manipulator mendapatkan lebih banyak reward dibandingkan yang dia peroleh ketika tidak melakukan manipulasi, ketika orang lain mendapatkan lebih kecil, minimal dalam jangka pendek (Christie dan Geis, 1970). Etika mempunyai hubungan dengan dimensi-dimensi etis seperti machiavellianisme. Machiavellian ini menjadi proksi perilaku moral yang mempengaruhi perilaku pembuatan keputusan etis. Tiga hal yang mendasari machiavellianisme (Christie, 1970), yaitu: (1) taktik manipulatif seperti tipu daya atau kebohongan; (2) pandangan atas manusia yang tak menyenangkan, yaitu lemah, pengecut dan mudah dimanipulasi; dan (3) kurangnya perhatian dengan moralitas konven-sional. Indikator dari machiavellianisme adalah sebagai berikut: (1) memanipulasi data atau infor-masi; (2) mempunyai sifat machiavellianisme; dan (3) kejujuran dalam memberi informasi. Variabel machiavellianisme akan diukur dengan menggunakan skala Likert dari interval 1 (sangat tidak setuju) hingga interval 5 (sangat setuju).

\section{Pertimbangan Etis}

Perilaku yang ditunjukkan oleh setiap individupun banyak yang dipengaruhi oleh pertimbangan- 


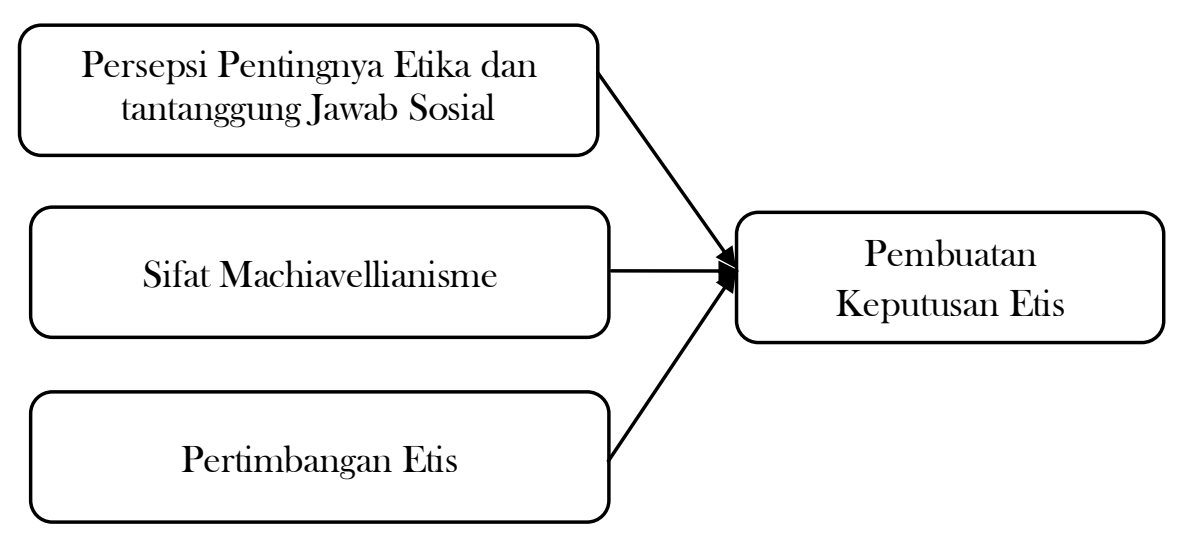

Gambar 1. Model Penelitian

pertimbangan etis. Semakin tinggi pertimbangan etis diharapkan semakin bermoral pula keputusan-keputusan yang diambilnya itu.Rest (1979) menyatakan bahwa pertimbangan etis didefinisikan sebagai pertimbangan-pertimbangan yang harus dilakukan untuk mengantisipasi dilema etis. Pertimbangan etis diukur menggunakan empat buah sketsa dilema etika, yang mungkin dihadapi oleh para konsultan pajak profesional. Indikator dari pertimbangan etis meliputi: (1) bersikap objektif; (2) bukti yang memadai; dan (3) sesuai standart dan etika yang berlaku. Variabel pertimbangan etis diukur dengan menggunakan skala Likert dari interval 1 (sangat tidak setuju) hingga interval 5 (sangat setuju).

\section{Variabel Dependen}

Jones (1991) mendefinisikan keputusan etis (ethical decision) sebagai sebuah keputusan yang baik secara moral maupun legal dapat diterima oleh masyarakat luas. Indikator dari pembuatan keputusan etis (Jones, 1991) adalah sebagai berikut: (1) isu moral; (2) pertimbangan moral; dan (3) perilaku moral. Variabel keputusan etis diukur dengan menggunakan skala Likert dari interval 1 (sangat tidak setuju) hingga interval 5 (sangat setuju).

\section{HASIL DAN PEMBAHASAN}

Berdasarkan data penelitian yang telah terkum-pul sebanyak 50 responden, maka diperoleh data tentang demografi responden yang terdiri dari: (1) jenis kelamin, (2) usia responden, (3) masa kerja responden, (5) jumlah sertifikat konsultan pajak yang dimiliki (lihat Tabel 2). Sebelum uji hipotesis dilakukan, instrument penelitian diuji validi tas dan reliabilitasnya terlebih dahulu. Pengujian vali-ditas dilakukan dengan menggunakan rumus korelasi product moment. Hasil pengujian validitas menunjukkan bahwa semua item yang terdiri dari pentingnya persepsi etika dan tanggung jawab sosial, sifat machiavellianisme, pertimbangan etis dan pembuatan keputusan etis masuk kartegori valid (lihat Tabel 3). Sedangkan pengujian reliabilitas menggunakan rumus cronbach alpha sebagaimana yang ditunjukkan Tabel 4. Hasil uji cronbach alpha ditemukan nilai lebih dari 0,5. Sehingga dapat disimpulkan hasil uji reliabilitas instrument juga lolos dan instrumen dapat dikatan reliable (Sofyani dan Akbar, 2013).

Selain uji instrumen, dilakukan pula uji asumsi klasik meliputi: uji normalitas, multikolinieritas, dan heteroskedastisitas. Dari hasil uji asumsi kalsik ditemukan bahwa data penelitian tidak mengalami masalah asumsi klasik. Hal ini dapat disimak dari titik sebaran data penelitian yang berada disekitar garis, titik scatter plot yang menyebar merata, dan nilai VIF yang lebih dari 1.

Tabel 2. Demografi Responden

\begin{tabular}{ccccccccccccc}
\hline & Jenis Kelamin & & \multicolumn{2}{c}{ Usia Responden (Tahun) } & \multicolumn{2}{c}{$\begin{array}{c}\text { Lama Menjadi } \\
\text { Konsultan (Tahun) }\end{array}$} & $\begin{array}{c}\text { Jumlah Sertifikat } \\
\text { Konsultan Pajak } \\
\text { yang Dimiliki }\end{array}$ \\
\hline Kriteria & Laki-Laki & $\begin{array}{c}\text { Perem- } \\
\text { puan }\end{array}$ & $20-30$ & $31-40$ & $41-50$ & $>50$ & $\leq 2$ & $2-5$ & $>5$ & 1 & $2-3$ \\
\hline Jumlah & 37 & 13 & 8 & 15 & 20 & 7 & 10 & 17 & 23 & 47 & 3 \\
\hline
\end{tabular}


Tabel 3. Hasil Pengujian Validitas

\begin{tabular}{|c|c|c|c|c|c|}
\hline No. & Indikator & Item & r Hitung & r Tabel & Keterangan \\
\hline \multirow[t]{3}{*}{1.} & 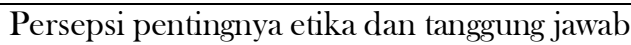 & $\mathrm{X} 1.1$ & 0,809 & 0,279 & Valid \\
\hline & sosial $\left(X_{1}\right)$ & $\mathrm{X} 1.2$ & 0,754 & 0,279 & \\
\hline & & $\mathrm{X} 1.3$ & 0,801 & 0,279 & \\
\hline \multirow[t]{3}{*}{2.} & Machiavellianisme $\left(\mathrm{X}_{2}\right)$ & X2.1 & 0,799 & 0,279 & Valid \\
\hline & & $\mathrm{X} 2.2$ & 0,701 & 0,279 & \\
\hline & & $\mathrm{X} 2.3$ & 0,836 & 0,279 & \\
\hline \multirow[t]{3}{*}{3.} & Pertimbangan Etis (X3) & X3.1 & 0,714 & 0,279 & Valid \\
\hline & & X3.2 & 0,817 & 0,279 & \\
\hline & & X3.3 & 0,769 & 0,279 & \\
\hline \multirow[t]{3}{*}{4.} & Pembuatan Keputusan etis $(\mathrm{Y})$ & Y1 & 0,698 & 0,279 & Valid \\
\hline & & Y2 & 0,821 & 0,279 & \\
\hline & & Y3 & 0,735 & 0,279 & \\
\hline
\end{tabular}

Tabel 4. Hasil Pengujian Reliabilitas

\begin{tabular}{lcc}
\hline Variabel & $\begin{array}{c}\text { Cronbach's } \\
\text { Alpha }\end{array}$ & Keterangan \\
\hline $\begin{array}{l}\text { Persepsi pentingnya } \\
\text { etika dan tanggung }\end{array}$ & 0,692 & Reliabel \\
jawab sosial & 0,675 & Reliabel \\
Machiavellanisme & 0,648 & Reliabel \\
$\begin{array}{l}\text { Pertimbangan Etis } \\
\text { Pembuatan }\end{array}$ & 0,617 & Reliabel \\
Keputusan etis & & \\
\hline
\end{tabular}

\section{Hasil Pengujian Hipotesis}

Ringkasan hasil pengujian hipotesis ditunjukkan pada Tabel 5. Berdasarkan hasil uji hipotesis satu ditemukan persepsi pentingnya etika dan tanggung jawab sosial berpengaruh terhadap pembuatan keputusan etis konsultan pajak, yang artinya hipotesis satu diterima.

\section{Tabel 5. Ringkasan Hasil Pengujian Hipotesis}

\begin{tabular}{lcc}
\hline Model & $\mathbf{t}$ & Sig. \\
\hline $\mathrm{X}_{1}$ & 5.795 & .000 \\
$\mathrm{X}_{2}$ & -4.597 & .000 \\
$\mathrm{X}_{3}$ & 6.690 & .000 \\
\hline Adjusted R Square & .734 & .000 \\
\hline
\end{tabular}

Hasil ini sejalan dengan Singhapakdi et al. (2001) yang menyatakan bahwa manajer harus terlebih dahulu mempersepsikan etika dan tanggung jawab sosial menjadi penting untuk efektivitas organisasi sebelum perilaku mereka akan menjadi lebih etis dan mencerminkan tanggung jawab sosial yang lebih besar. Hasil ini juga mendukung studi Singhapakdi et al. (1995) yang juga menemukan ada hubungan positif antara nilai-nilai etika perusahaan pemasar dan persepsi-persepsinya mengenai pentingnya etika dan tanggung jawab sosial.

Di praktek perpajakan, hasil ini mendukung studi Shafer dan Simmons (2008) yang menemukan bahwa praktisi profesional pajak di Hong Kong yang mempersepsikan etika perusahaan dan tanggung jawab sosial lebih penting akan menilai penghindaran (avoidance) agresif kurang menguntungkan, dan karenanya akan memperkirakan kemungkinan yang lebih rendah dari persetujuan dalam skema tersebut. Hasil studi ini sejalan dengan Jiwo (2011) yang mengatakan bahwa persepsi pentingnya etika dan tanggung jawab sosial berpengaruh terhadap pembuatan keputusan etis.

Hasil penelitian ini menyatakan bahwa persepsi pentingnya etika dan tanggung jawab sosial berpengaruh positif terhadap pembuatan keputusan etis oleh konsultan pajak. Jadi pada penelitian ini mempunyai pengaruh yang positif untuk konsultan pajak dalam pembuatan keputusan etis. Dengan pengaruh positif ini konsultan pajak dapat lebih banyak membuat persepsi-persepsi etika dalam profesinya dan lebih bertanggung jawab lagi atas jasanya agar tidak melanggar kode etik konsultan pajak saat memberikan jasa pada kliennya. Namun hasil uji hipotesis pertama ini tidak sejalan dengan Krismanto (2014), menjelaskan persepsi pentingnya etika dan tanggung sosial tidak berpengaruh pada pembuatan keputusan etis konsultan pajak, karena konsultan pajak hanya berfokus pada legalitas tanpa mempertimbangkan pada esensi sebenarnya yang ada dalam undang-undang dan kode etik profesinya.

Berdasarkan hasil uji hipotesis dua dapat disimpulkan bahwa sifat machiavellianisme $\left(\mathrm{X}_{2}\right)$ berpengaruh negatif terhadap pembuatan keputusan etis (Y) oleh konsultan pajak, yang artinya hipotesis dua diterima. Hasil uji hipotesis 2 ini konsisten dengan hasil studi sebelumnya yang dilakukan Richmond (2001), Purnamasari (2006) Shafer dan Simmons (2008), Jiwo (2011), Murphy (2012), dan Nida (2014) yang juga menemukan bahwa machiavellian menunjukkan nilai-nilai etika yang rendah. Richmond (2001) menjelaskan bahwa kecenderungan sifat machiavellian yang semakin tinggi menggiring seseorang untuk berperilaku tidak etis. Sebaliknya, jika kecenderungan sifat machiavellian rendah maka seseorang akan cenderung untuk 
berperilaku etis. Hasil studi ini juga sejalan dengan Purnamasari (2006), individu dengan sifat machiavellian tinggi cenderung memanfaatkan situasi untuk mendapatkan keuntungan pribadi dan lebih memiliki keinginan untuk tidak taat pada aturan.

Studi Shafer dan Simmons (2008)-yang menguji pengaruh machiavellianisme pada kesediaan praktisi pajak profesional di Hong Kong untuk mengadvokasi skema penghindaran agresif atas nama klien perusahaan-juga menemukan bahwa praktisi pajak profesional dengan orientasi machiavellian kuat lebih cenderung menilai skema penghindaran pajak agresif menguntungkan. Juga sejalan dengan hasil studi Murphy (2012) yang menemukan bahwa akuntan machiavellian lebih cenderung melaporkan laporan keuangan secara keliru dibandingkan dengan machiavellianism yang lebih rendah. Studi Jiwo (2011) menemukan sifat machiavellian berpengaruh negatif secara signifikan terhadap pembuatan keputusan etis oleh konsultan pajak di KAP di kota Semarang. Nida (2014) menemukan sifat machiavellian berpengaruh negatif terhadap inde-pendensi auditor pada KAP yang terdaftar pada directory Institut Akuntan Publik Indonesia (IAPI) wilayah Bali.

Berdasarkan hasil studi ini, maka dapat direkomendasikan kepada Direktur Jenderal Pajak atau pejabat yang ditunjuk dalam menerbitkan izin praktik konsultan pajak perlu melakukan suatu uji sifat machiavellianisme dari konsultan pajak tersebut. Tujuanya adalah agar kebijakan ini dapat meminimalisir jumlah konsultan pajak yang memiliki sifat machiavellianisme yang cenderung tinggi. Hal itu dikarenakan jika konsultan pajak cenderung memiliki sifat machiavellianisme maka akan dipandang buruk oleh klien yang menggunakan jasanya dan sulit dipercaya untuk kejujurannya. Kualitas seseorang atau konsultan pajak pun dapat dinilai masyarakat dalam hal tersebut.

Berdasarkan hasil uji hipotesis tiga ditemukan bahwa pertimbangan etis berpengaruh positif terhadap pembuatan keputusan etis oleh konsultan pajak, yang artinya hipotesis tiga diterima. Hasil dari penelitian ini dapat disimpulkan bahwa pertimbangan etis berpengaruh positif pada pembuatan keputusan etis. Hasil ini sejalan dengan penelitian Jiwo (2011) menyarankan individu yang berkembang dengan moral yang lebih baik, kecil kemungkinannya berperan dalam kepribadian yang tidak etis. Dengan tingkat pertimbangan etis yang tinggi mampu untuk mengambil pertimbangan etis secara independen tanpa pengaruh dari klien maupun rekan kerja di kantor dengan lebih baik. Penelitian ini juga sejalan dengan Purnamasari (2006) pertimbangan etis berpengaruh tinggi akan lebih baik dalam menghadapi konflik dan dilema etis, bahwa individu yang lebih berkembang secara moral (pertimbangan etisnya lebih tinggi) kemungkinannya akan lebih kecil untuk menyetujui perilaku yang tidak etis dan lebih independen dalam membuat keputusan yang terkait dengan dilema etis. Oleh karenanya, perlu dipastikan bahwa konsultan pajak yang mendapatkan ijin praktik adalah individu yang memiliki kematangan moral tertinggi (tahap post conventiona).

Berdasarkan analisis statistik diperoleh nilai koefisien determinasi $\left(R^{\beta}\right)$ yang dilihat dari adjusted $R$ square sebesar 0,743. Hal ini berarti $74,3 \%$ pembuatan keputusan etis yang diambil konsultan pajak dapat dijelaskan oleh variabel bebas yang terdiri dari persepsi pentingnya etika dan tanggung jawab sosial, machiavellanisme dan pertimbangan etis sedangkan sisanya yaitu 25,7\% dipengaruhi oleh variabel lain yang tidak diteliti dalam penelitian ini.

\section{SIMPULAN}

Studi ini bertujuan untuk menguji pengaruh faktor-faktor internal individual dalam pembuatan keputusan etis oleh konsultan pajak. Data diperoleh dari kuesioner yang disebar kepada 50 konsultan pajak bersertifikat, yang bekerja pada $50 \mathrm{KKP}$ di kota Surabaya. Simpulan yang dapat ditarik yaitu persepsi pentingnya etika dan tanggung jawab sosial yang merupakan faktor indi-vidual dari konsultan pajak yang berpengaruh positif terhadap pembuatan keputusan etis. Artinya, bahwa tinggi atau tidaknya persepsi pentingnya etika dalam diri seseorang memiliki pengaruh yang kuat terhadap pembuatan keputusan etis. Hal ini mengindikasikan, bahwa seseorang yang berpersepsi tinggi dengan pentingnya etika dan tanggung jawab memicu orang tersebut akan melakukan pembuatan keputusan yang etis.

Selanjutnya, sifat machiavellianisme yang merupakan faktor individual dari konsultan pajak yang berpengaruh negatif terhadap pembuatan keputusan etis konsultan pajak. Hal ini berarti bahwa sifat machiavellian yang tinggi pada seorang individu menyebabkan individu tersebut memiliki kemungkinan besar untuk membuat keputusan yang tidak etis. Studi ini juga menemukan bahwa pertimbangan etis yang merupakan faktor individual dari konsultan pajak berpengaruh positif terhadap pembuatan keputusan etis. Artinya meningkatnya pertimbangan etis dapat mendorong konsultan pajak untuk lebih banyak melakukan pertimbangan-pertimbangan yang baik agar dapat membuat keputusan etis secara benar dan tidak dibenar-benarkan. 
Studi ini memiliki kontribusi sebagai berikut: pertama, persepsi pentingnya etika dan tanggung jawab sosial, sifat machiavellianisme, pertimbangan etis dapat menjelaskan pengaruh terhadap pembuatan keputusan etis oleh konsultan pajak. Hal ini mempunyai kontribusi teori yaitu menerapkan teori pengambilan keputusan etis (Ferrell dan Gresham, 1985) terkait dengan faktor individual. Kedua, hasil studi ini dapat dimanfaatkan oleh Direktur Jenderal Pajak atau pejabat yang ditunjuk dalam menerbitkan izin praktik konsultan pajak. Perlu melakukan suatu uji sifat machiavellianisme dari konsultan pajak tersebut. Tujuanya agar meminimalisir jumlah konsultan pajak yang memiliki sifat machiavellianisme yang cenderung tinggi. Selain itu, juga perlu dipastikan bahwa konsultan pajak yang mendapatkan ijin praktik adalah individu yang memiliki kematangan moral tertinggi (tahap post conventional), sehingga kemungkinannya akan lebih kecil untuk menyetujui perilaku yang tidak etis dan lebih independen dalam membuat keputusan yang terkait dengan dilema etis.

Penelitian ini memiliki beberapa keterbatasan, yakitu: sampel penelitian ini hanya menggunakan konsultan pajak bersertifikat di KKP kota Surabaya. Penelitian selanjutnya, dapat memperluas populasi di seluruh KKP di wilayah Jawa Timur bahkan seluruh Indonesia. Selanjutnya, sampel penelitian ini 94\% merupakan konsultan pajak bersertifikat A dan hanya 6\% merupakan konsultan pajak bersertifikat B dan C. Klasifikasi sertifikat konsultan pajak menunjukkan tingkat keahlian untuk memberikan jasa di bidang perpajakan kepada wajib pajaknya. Tingkat dilema keputusan etis yang akan dibuat antara konsultan pajak bersertifikat A kemungkinan akan berbeda dengan konsultan pajak bersertifikat B dan C. Oleh karenanya, penelitian selanjutnya dapat diuji kembali dengan mempertimbangkan klasifikasi sertifikat konsultan pajak yang dimiliki konsultan pajak. Terakhir, penelitian ini belum menguji faktor ekternal yang juga mempengaruhi pembuatan keputusan etis oleh konsultan pajak. Oleh karenanya, penelitian selanjutnya dapat menambahkan faktor eksternal yang mempengaruhi pembuatan keputusan etis oleh konsultan pajak.

\section{LAMPIRAN}

\section{Intrumen Penelitian}

\section{Persepsi Pentingnya Etika dan TanggungJawab Sosial}

(1) Sebagai seorang konsultan pajak, saya bertanggungjawab terhadap profesi yang telah saya pilih.

(2) Prinsip kehati-hatian dalam bekerja selalu saya terapkan saat bekerja.

(3) Saat memberikan jasa pada client, saya bekerja sesuai dengan kode etik yang ditetapkan.

\section{Machiavellianisme}

(1) Saya mampu menghadapi situasi penuh tekanan.

(2) Kejujuran adalah hal terbaik dalam kondisi apapun.

(3) Dalam segala hal rendah hati dan jujur lebih baik daripada terpandang (berkuasa) dan tidak jujur

\section{Pertimbangan Etis}

(1) Saat membuat keputusan, saya bersikap objektif.

(2) Penarikan kesimpulan saya yang saya ambil didukung sejumlah bukti yang memadai.

(3) Saat dilemma membuat keputusan, saya harus berpegang teguh kepada standart dan etika yang berlaku dengan tetap mempertimbangkan agar rekomendasi dilaksanakan.

\section{Keputusan Etis}

(1) Saya menerapkan sikap kejujuran dalam menjalankan tugas.

(2) Keputusan etis yang saya buat berpegang teguh pada kebenaran data yang saya dapatkan.

(3) Saya menghindari pelanggaran aturan dalam bekerja

\section{DAFTAR PUSTAKA}

Achmad, T. 2014. Menjadikan Konsultan Pajak sebagai Agents of Tax Compliance. Website: http://www. pajak.go.id/ content/article/ 
menjadikan-konsultan-pajak-sebagai-agents-taxcompliance

Amarullah, A. 2010. 13 Konsultan Pajak di Surabaya Ditahan. Website: http:// nasional.news.viva. co.id/news/read/148362-13_konsultan_pajak_ di_surabaya_ditahan

Anton. 2012. Analisis Persepsi Akuntan Publik dan Mahasiswa Akuntansi terhadap Kode Etik Ikatan Akuntan Indonesia (Studi Kasus pada Beberapa Universitas serta Beberapa Kantor Akuntan Publik di Semarang). Makalah Ilmiah INFORMATIKA, 3 (2), 1-34.

Arif, M. L. S., R. Aulia dan N. Herawati. 2014. Bagaimanakah Persepsi Mahasiswa Akuntansi tentang Praktik Akuntansi Kreatif Ditinjau dari Teori Etika Bisnis?. Jurnal Akuntansi Multiaparadigma, 5 (1), 96-112.

Beritasatu. 2012. Konsultan Pajak Jadi Tersangka Baru Kasus Dhana Widyatmika. Website: http://www. beritasatu.com/nasional/57766konsultan-pajak-jadi-tersangka-baru-kasusdhana-widyatmika.html

Blanthorne, C., H. A. Burton dan Fisher, D. 2014. The Aggressiveness of Tax Professional Reporting: Examining the Influence of Moral Reasoning. Advances in Accounting Behavioral Research, 16, 149 - 181.

Bobek, D. D., A. M. Hageman dan R. R. Radtke. 2010. The Ethical Environment of Tax Professionals: Partner dan Non-Partner Perceptions dan Experiences. Journal of Business Ethics, 92 (4), 637-654.

Budileksmana, A. 2000. Manfaat dan Peranan Konsultan Pajak dalam Era Self Assesment Perpajakan. Jurnal Akuntansi dan Investasi, 1 (2), 77-84.

Burns, J. O. dan P. Kiecker. 1995. Tax Practitioner Ethics: An Empirical Investigation of Organizational Consequences. The Journal of the American Taxation Association, 17 (2), 2049.

Cash, L. S., T. L. Dickens dan M. E. Mowrey 2007. The Ethics Environment in Which Tax Professionals Practice. Taxes-The Tax Magazine, 43-55.

Chrismastuti, A. A. dan S. V. Purnamasari. 2004. Hubungan Sifat Machiavellian, Pembelajaran Etika dalam Mata Kuliah Etika, dan Sikap Etis Akuntan: Suatu Analisis Perilaku Etis Akuntan dan Mahasiswa Akuntansi di Semarang. Paper Dipresentasikan pada Acara Simposium Nasional Akuntansi VII, Denpasar.

Christie, R., dan F. L. Geis. 1970. Machiavellianism. Academic Press, Incorporated.
Damayanti, T. W. 2004. Pelaksanaan Self Assesment System menurut Persepsi Wajib pajak (Studi pada Wajib pajak Badan Salatiga). Jurnal Ekonomi dan Bisnis (Dian Ekonomi), X (1), 109-128.

Devos, K. 2012. The Impact of Tax Professionals Upon the Compliance Behavior of Australian Individual Taxpayers, Revenue Law Journal, 22 (1), 1-26.

Doyle, E., J. F. Hughes dan B. Summers. 2013. An Empirical Analysis of the Ethical Reasoning of Tax Practitioners, Journal of Business Ethics, 114 (2), 325-339.

Doyle, E., J. F. Hughes dan B. Summers. 2014. Ethics in Tax Practice: A Study of the Effect of Practitioner Firm Size. Journal of Business Ethics, 122 (4), 623-641.

Ferrell O. C. dan L. G. Gresham. 1985. A Contingency Framework for Understanding Ethical Decision Making in Marketing. Journal of Marketing, 49 (3), 87-96.

Fleischman, G. M., S. Valentine dan D. W. Finn. 2007. Ethical Reasoning dan Equitable Relief. Behavioral Research in Accounting, 19 (1), 107-132.

Hughes, F. J. dan P. Moizer. 2015. Assessing the quality of services provided by UK tax practitioners. eJournal of Tax Research, 13 (1), 5175.

Gray, K., L. Young dan A. Waytz. 2012. Mind Perception Is the Essence of Morality. Psychological Inquiry, 23, 101-124.

Gupta, R. 2015. Relational Impact of Tax Practitioners' Behavioural Interaction dan Service Satisfaction: Evidence from New Zealand. eJournal of Tax Research, 13 (1), 76-107.

Hudson, S. dan G. Miller. 2005. Ethical Orientation dan Awareness of Tourism Students. Journal of Business Ethics, 62 (4), 383-396.

Hunt, S. dan S. Vitell. 1986. A General Theory of Marketing Ethics. Journal of Macromarketing, $6(5), 5-16$.

Jawa Pos, 15 Desember 2008. Aturan Baru, Saatnya Konsultan Pajak Panen. Website:http://www. antikorupsi.org/id/content/aturan-baru-saatnyakonsultan-pajak-panen

Jefriando, M. 2015. Konsultan Pajak yang Seperti Ini Harusnya Masuk Neraka Paling Bawah. Detikfinance Selasa, 27/01/2015, Website: http://finance. detik.com/read/ 2015/01/27/ 120118/2815038/4/konsultan-pajak-yangseperti-ini-harusnya-masuk-neraka-palingbawah

Jiwo, P. 2011. Analisis Faktor-Faktor Individual dalam Pengambilan Keputusan Etis oleh 
Konsultan Pajak. (Kä̈an Empiris pada Konsultan Pajak di KAP di Kota Semarang). SE Skripsi, Universitas Diponegoro Semarang.

Jones, T. M. 1991. Ethical Decision Making by Individual in Organizations: An Issue-Contingent Model. Academy of Management Review, 16 (2), 366-39S.

Krismanto, F. I. J. 2014. Pengaruh Persepsi Pentingnya Etika dan Tanggung Jawab Sosial, Sifat Machiavellian, dan Pertimbangan Etis Konsultan Pajak terhadap Pengambilan Keputusan Etis (Survey pada Konsultan Pajak dan Staff Pajak di Beberapa Kantor Konsultan Pajak Bandung). Skripsi, Universitas Widyatama.

Kohlberg, L. 1976. Moral stages and moralization: The cognitive-developmental approach. Moral Development and Behavior: Theory, Research, And Social Issues, 31-53.

Kurniawan, C. dan A. Sadjiarto. 2013. Pemahaman Kode Etik Ikatan Konsultan Pajak Mengenai Hubungan dengan Wajib pajak oleh Konsultan Pajak di Surabaya. Tax \& Accounting Review, 1 (1), 55-62.

Kurpis, L. V., M. S. Beqiri dan J. G. Helgeson. 2008. The Effects of Commitment to Moral Selfimprovement and Religiosity on Ethics of Business Students. Journal of Business Ethics, 80 (3), 447-463.

Murphy, P. R. 2012. Attitude, Machiavellianism and the rationalization of misreporting. Accounting, Organizations and Society, 37 (4), 242259.

Nida, D. R. P. P. 2014. Pengaruh Persaingan, Pemberian Jasa Lain dan Sifat Machiavellian pada Independensi Auditor. E-Jurnal Akuntansi Universitas Udayana, 7 (3), 778-790.

Novianti, L. 1997. Penerapan System Self Assessment terhadap Pemungutan PPh Orang Pribadi, Suatu Tinjauan Pelaksanaan Pemungutan PPh Orang Pribadi pada Pemilik Rumah Kost. Skripsi, Universitas Airlangga .

Nugrahaningsih, P. 2005. Analisis Perbedaan Perilaku Etis Auditor di KAP dalam Etika Profesi (Studi terhadap Peran Faktor-Faktor Individual: Locus of Control, Lama Pengalaman Kerja, Gender, dan Equity Sensitivity). Paper Dipresentasikan pada Acara Simposium Nasional Akuntansi VIII, Solo.

Peraturan Menteri Keuangan Republik Indonesia Nomor 111/PMK.03/2014 tentang Konsultan Pajak.

Ponemon, L. A. 1992. Ethical Reasoning dan Selection-Socialization in Accounting. Accoun- ting, Organizations dan Society, 17 (3-4), 239258.

Pramono, H. dan D. U. Ario. 2009. Pengaruh Personal Values terhadap Pengambilan Keputusan Etis Akuntan Publik. Among Makarti, 2 (4), 9-22.

Purnamasari, S. V. 2006. Sifat Machiavellian dan Pertimbangan Etis. Paper Dipresentasikan pada Acara Simposium Nasional Akuntansi IX, Padang.

Ramadhani, T. S. 2015. Pengaruh Sifat Machiavellian, Locus of Control, dan Equity Sensitivity terhadap Penghindaran Pajak dengan Keputusan Etis sebagai Variabel Intervening (Studi Empiris Pada Wajib pajak Orang Pribadi yang Melakukan Usaha dan Pekerjaan Bebas yang Terdaftar di KPP Pratama Pekanbaru Senapelan). Jom. FEKON, 2 (2), 115.

Rayburn, J. M. dan Rayburn, L. Gayle. 1996. Relationship Between Machiavellianism dan Type A Personality dan Ethical-Orientation. Journal of Business Ethics, 15 (11), 1209-1219.

Rest, J. R. 1979. Revised manual for the defining issues test. Unpublished manuscript, University of Minnesota.

Rest, J. R. 1986. Moral development: Advances in research and theory. Praeger Publishers.

Rest, J., S. J. Thoma, D. Narvaez dan M. J. Bebeau. 1997. Alchemy and beyond: indexing the Defining Issues Test. Journal of educational psychology, 89 (3), 498.

Richmond, K. A. 2001. Ethical Reasoning, Machiavellian Behavior, dan Gender: The Impact on Accounting Students' Ethical Decision Making. Phd Dissertation, Virginia Polytechnic Institute dan State University.

Safitri, A. 2013. Mengenai Pengaruh Etika, Motivasi, Komitmen, Independensi dan Tenure terhadap Kinerja Auditor. Skripsi, Universitas Trunojoyo Madura.

Sari, R. S. N., R. Zuhdi dan N. Herawati. 2012. Tafsir Perilaku Etis Menurut Mahasiswa Akuntansi Berbasis Gender. Jurnal Akuntansi Multiaparadigma, 3 (1), 125-133.

Shafer, W. E. dan R. S. Simmons. 2008. Social Responsibility, Machiavellianism dan Tax Avoidance: A Study of Hong Kong Tax Professionals, Accounting, Auditing \& Accountability Journal, 21 (5), 695 - 720.

Singhapakdi, A., K. Karande, C. P. Rao dan S. J. Vitell. 2001. How Important are Ethics dan Social Responsibility? A Multinational Study of Marketing Professionals. European Journal of Marketing, 35 (1-2), 133, 134. 
Singhapakdi, A., K. L. Kraft, S. J. Vitell dan K. C. Rallapalli. 1995. The Perceived Importance of Ethics dan Social Responsibility on Organizational Effectiveness: A Survey of Marketers. Journal of the Academy of Marketing Science, 23 (1), 49-56.

Singhapakdi, A., S. J. Vitell, K. C. Rallapalli dan K. L. Kraft. 1996. The Perceived Role of Ethics dan Social Responsibility: A Scale Development. Journal of Business Ethics, 15 (11), 1131-1140.

Sofyani, H. dan R. Akbar. 2013. Hubungan Faktor Internal Institusi dan Implementasi Sistem Akuntabilitas Kinerja Instansi Pemerintah (SAKIP) di Pemerintah Daerah. Jurnal Akuntansi dan Keuangan Indonesia, 10 (2), 184205.

Sukrisno, A. 1996. Penegakan Kode Etik Akuntan Indonesia. Makalah dipresentasikan pada acara KNA-KLB IAI, Semarang.
Sweeney, J. T. dan R. W. Roberts. 1997. Cognitive Moral Development dan Auditor Independence. Accounting, Organizations dan Society, $22(3 / 4), 337-352$.

Tan, L. M. 1999. Taxpayers' Preference for Type of Advice from Tax Practitioner: A Preliminary Examination. Journal of Economic Psychology, 20 (4), 431-447.

Tarjo dan I. Kusumawati. 2006. Analisis Perilaku Wajib pajak Orang Pribadi terhadap Pelaksanaan Self Assessment System: Suatu Studi di Bangkalan. Jurnal Akuntansi dan Auditing Indonesia, 10 (1), 101 - 120.

Wakefield, R. L. 2008. Accounting dan Machiavellianism. Behavioral Research in Accounting, 20 (1), 115-129

Wisesa, A. 2011. Integritas Moral dalam Konteks Pengambilan Keputusan Etis. Jurnal Manajemen Teknologi, 10 (1), 82-92. 